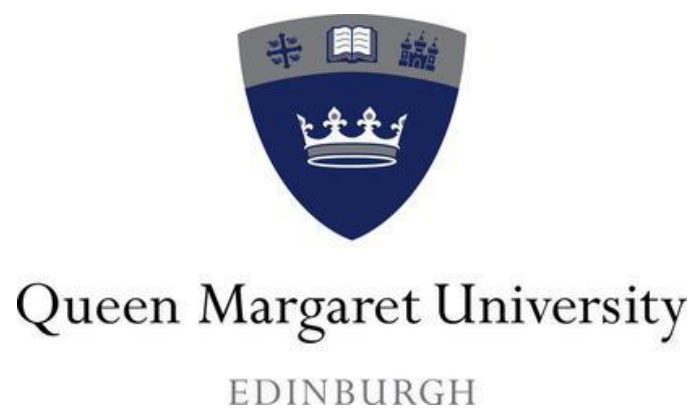

\title{
Facebook and political participation: Going beyond over-optimistic predictions
}

Isidoropaolo Casteltrione, Queen Margaret University

icasteltrione@qmu.ac.uk

\section{SUGGESTED CITATION}

Casteltrione, I. (2017), 'Facebook and political participation: Going beyond over-optimistic predictions', Northern Lights, 15, pp. 131-48, doi: 10.1386/nl.15.131_1

Link to the full text version of the article on IngentaConnect:

http://www.ingentaconnect.com/contentone/intellect/nl/2017/00000015/00000001/art00008 


\begin{abstract}
In the last decade there has been a proliferation of academic studies examining the links between social networking websites (SNSs) and citizens' political participation. Focusing on Facebook and on the specific contexts of Italy and the United Kingdom, this article adds to this strand of research and explores the limitations of this SNS as a political platform. The findings indicate three possible factors limiting the contributions of Facebook to political participation, namely, the non-universality of Facebook, its questionable credibility as a political information source and the enduring relevance of the offline dimension of political participation. In the light of these results, the article goes on to argue that the mobilizing force of Facebook rests, at least in part, on its connection with the offline world. Moreover, the research evidence underpinning this article suggests that the most effective way in which Facebook can aid political participation is, perhaps, by bridging the online-offline divide, integrating and supporting other media and offline activities.
\end{abstract}

\title{
Keywords
}

political participation

Facebook

social networks

Italy

United Kingdom

limitations

offline 


\section{Introduction: A political communication study}

Due to the widespread and rapid penetration of social networking websites (SNSs) - web-based services that 'allow individuals to present themselves, articulate their social networks, and establish or maintain connections with others' (Ellison et al. 2007: 1143) - into diverse segments of the worldwide population, in the last few years there has been an outbreak of news stories and academic and non-academic studies concentrating on these platforms. This trend is likely to carry on considering how embedded SNSs have become in many individuals' daily routines, and the consequences that their adoption can have on disparate aspects of people's lives - ranging from less serious matters such as shopping and organization of recreational activities, to more weighty affairs like the coordination of protest movements. Given the role SNSs played in the Arab Spring and in political campaigns such as the 2008 Obama's presidential campaign, an increasing number of investigations have examined how these platforms can contribute to political campaigning, engagement and participation (e.g. Lim 2012; Papacharissi 2015; Towner 2013; Vitak et al. 2011).

The present article adds to this stream of research by exploring - from the perspective of political communication - the factors that limit the contributions of Facebook to political participation. Political communication, broadly defined as 'the role of communication in the political process' (Chaffee 1975: 15), is highly interdisciplinary, drawing on concepts from several fields such as mass communication, political science, sociology and psychology (Semetko and Scammell 2012). The research on which this article is based can be considered a textbook political communication study in that it inherits the interest in attitudes, opinions and beliefs from social psychology (Ryfe 2001), while borrowing its focus on behaviours from the behaviourist school of political science (see Dahl 1961). Finally, by investigating the effects of 
Facebook usage on citizens' political participation, this study assumes an effects-style approach in the fashion of mass communication research (Lievrouw 2009).

\section{SNSs and political participation research}

Political participation is a widely investigated subject in academic studies. It is a multidimensional phenomenon (Casteltrione 2015) encompassing activities that can differ highly in terms of the resources they require (e.g. time and skills) and the purposes driving them. As a concept political participation extends from attempts to influence governments' actions (Verba et al. 1995) to discursive performance designed to express a political identity (Marichal 2013). Drawing on Verba et al.'s theorization of voluntary political participation (1995) and Christy's conceptualization of communication activities (1987), in this article, political participation is defined as a set of activities aiming to influence governments' actions and other individuals' political behaviours, and/or to reflect individuals' interest and psychological involvement in politics.

The multifaceted nature of political participation is also stressed by Vedel (2007) who proposes three axes for making sense of the political uses of the Internet, namely, information, discussion and mobilization. In relation to the information axis, research attests to the relevance of SNSs as information sources and finds that one of the main motivations behind their usage is the gathering of political information (Baresch et al. 2011; Mitchell et al. 2013; Rainie and Smith 2012; Weeks and Holbert 2013). Concerning the political discussion axis, Kushin and Kitchener (2009) recognize that these platforms have created unprecedented opportunities for human-tohuman interaction and grown into a unique arena for online discussion. Likewise, Bae (2013) 
highlights the growing centrality of SNSs as a venue for citizens' political conversations. Along the same lines, focusing on political talk - namely a 'non-purposive, informal, casual, and spontaneous political conversation voluntarily carried out by free citizens, without being constrained by formal procedural rules and predetermined agenda' (Kim and Kim 2008: 54) Wright et al. (2016) argue that SNSs are arenas in which political talk is present and can even thrive. With respect to the mobilization dimension SNSs have assumed a key role in activists' repertoires. Obar et al. (2012) find that members of advocacy groups employ social media to communicate with citizens on a daily basis, and believe that these platforms have aided them in their advocacy and organizational efforts. Lim (2012) explains that in Egypt social media enabled activists to reach and expand networks of disaffected Egyptians, frame issues, propagate messages and transform online activism into offline protests. In a similar fashion, Valenzuela et al. (2012) and Theocharis (2011) find that SNSs like Facebook were instrumental to the organization and coordination of Chilean and Greek youths' protest activity. Warren et al. (2014) reveal that activists use Facebook to seek and obtain information, promote social events, call for donations and volunteers, schedule plans and discuss social issues. In a qualitative study involving Australian, American and British activists, Vromen et al. (2015) confirm these findings and establish that all the studied groups embraced - whether enthusiastically or reluctantly - Facebook as an organizational tool.

Finally, there are also numerous general studies focusing on political participation that share such a techno-optimistic stance and establish that SNSs can aid and promote citizens' political participation (Baek 2015; Bond et al. 2012; Gil de Zúñiga et al. 2012; Holt et al. 2013; Towner 2013; Xenos et al. 2014). Among the various techno-optimist scholars, Castells (1996, 2010, 2012) has strongly influenced the field and deserves a particular mention. In Networks of 
Outrage and Hope he analyses the role of the Internet in the Arab Spring, the Spanish Indignados and the Occupy Wall Street movement, concluding that 'the digital social networks based on the Internet and on wireless platforms are decisive tools for mobilizing, for organizing, for deliberating, for coordinating and for deciding' (Castells 2012: 229).

However, there are voices outside the optimist chorus on the impact of SNSs on political participation. Within this more cautious research strand it is possible to identify two other schools of thought: the normalizers and the pessimists. The normalizers sit somewhere in the middle between the optimists and pessimists, and emphasize the tendency of SNSs to reinforce existing participatory patterns by mainly aiding those citizens already interested in politics (Carlisle and Patton 2013; Gustafsson 2012; Mascheroni 2012; Vesnic-Alujevic 2012; Vitak et al. 2011; Yoo and Gil de Zúñiga 2014). These scholars follow in the tradition of academics such as Bimber (2003) or Tedesco (2004) who, focusing on the Internet in general, argue that even if digital technologies have in part transformed the ways of doing politics, they have not changed who participate in politics (Bimber 2003), providing politically interested citizens with further ways to engage and participate (Tedesco 2004).

Lastly, at the other end of the continuum there is a group of academics assuming a more pessimistic stance. In their study exploring the reasons why members of the public visited MySpace profiles of 2008 US primary candidates, Ancu and Cozma (2009) determine that users are attracted to MySpace mainly because they desire social interaction with other like-minded individuals, a type of usage negatively related to campaign involvement in the study. Fenton and Barassi (2011) also argue that SNSs have a negative influence on political participation. They contend that such negative effects are linked to the tendency of these platforms to foster individualism and personal affairs, which disconnect individuals from the public terrain of 
political participation and guide them away from the communality of collective political endeavour (Fenton and Barassi 2011). Similarly, Marichal (2013) asserts that digital technologies, instead of fostering citizens' mobilization, can facilitate microactivism. Microactivism includes actions such as creating political Facebook groups and uploading political videos on YouTube, and it is a form of political participation that does not aim to affect governments' actions, but echoes micro-level intentions (Marichal 2013). Morozov (2011) argues that microactivism can negatively affect citizens' political engagement in that it facilitates slacktivism, which encompasses activities that satisfy people's needs for social connection but detract from more formal and meaningful types of political participation, therefore having no impact on political outcomes. Likewise, Fuchs (2014) offers a critical account of social media. Drawing on a number of examples such as the Arab Spring and the Occupy movement, he questions the emancipatory capabilities of social media and the notion of Twitter and Facebook revolutions.

Fuchs warns of the dangers of deterministic approaches and emphasizes that the effects of social media are as contradictory as the society we live in. Thus, he argues that 'the Internet is a techno-social system... embedded in the antagonisms of contemporary society and therefore has no in-built effects or determinations' (Fuchs 2014: 84).

\section{Research question}

A review of research looking into the contributions of SNSs to political participation reveals that over-optimistic findings and predictions characterize numerous studies falling within this subject area. The work of Fuchs (2014) and other scholars highlight that such an enthusiasm is not always justified, and that more balanced and cautious approaches are needed when studying the 
links between digital technologies and politics. Responding to this call for caution, the present article examines how Facebook can contribute to political participation. However, rather than focusing on the affordances of this SNS (see Casteltrione 2016 for such an account) it explores its limitations. Accordingly, one general research question shapes the argument of this article:

RQ: Focusing on British and Italian Facebook users, what are the limitations of Facebook as a political participation platform?

Rather than seeking contextual differences, the article aims to identify possible analogies between British and Italian Facebook users, offering a critical reflection that goes beyond national contexts. This enables us to complement the work of scholars such as Fuchs and demonstrate that, despite the need of acknowledging contextual particularities, studies that provide arguments more general in scope remain useful and can contribute to the development of the field.

\section{Methodology}

\section{Adopting a cross-national approach}

Unlike numerous investigations in this area - a gap highlighted by Boulianne (2015) in her metaanalysis of research on social media use and participation in civic and political life - the present article adopts a cross-national approach. Warnick and Osherson (1973) observe that crossnational research can facilitate the assessment of the generalizability of findings by testing them in diverse settings (see also Moy et al. 2012). Furthermore, comparative cross-national research 
can also perform a heuristic function, providing an effective venue for the generation of hypotheses and theories (Warnick and Osherson 1973). This is also stressed by Nowak, who even argues that 'in order to formulate and to test our theory in its general formulation, we usually need a cross-national study' (1997: 15). In light of its assets, it is evident how the crossnational comparative method can aid the researcher in offering a critical reflection that goes beyond national contexts and identifying more general inhibitors of Facebook political participation.

Livingstone (2003) identifies a series of theoretical and practical decisions that researchers have to make when engaging in cross-national research. These decisions include the selection of countries, the degree of methodological standardization to pursue and the position to assume on the emic-etic continuum - the emic approach aims to assess how attitudinal and behavioural phenomena are expressed uniquely in each culture, while the etic approach is primarily interested in identifying universals (Moutinho and Hutcheson 2011) - when interpreting the data. In regard to this latter decision, an etic approach was adopted in the present article, and analogies rather than differences were sought for. A high degree of methodological standardization was also pursued and attention was devoted to guaranteeing equivalence in samples selection and recruitment, data collection methods and measurement procedures. With respect to the selection of countries, three considerations have guided the selection of Italy and the United Kingdom. First, these two countries are characterized by somewhat comparable political participatory trends. Many British and Italian citizens are, in fact, dissatisfied with mainstream political parties and institutions (Curran et al. 2014), and participation in formal party politics has decreased sharply in the two countries over the last two decades (Donovan and Onofri 2008; Whiteley 2012). The second reason is the similar penetration of Facebook in Italy 
and the United Kingdom at the time of the data collection (Socialbakers 2012): today, Facebook remains the most popular SNS in these two countries (Facebook 2017). Finally, Italy and the United Kingdom were also chosen because they are the countries with which the researcher is most familiar, and his substantive knowledge is an advantage practically and methodologically in that it can facilitate equivalence in the cross-national comparison (Landman 2008).

Hence, considering the theory generation capacity of few-countries studies (Landman 2008), the researcher' s background knowledge of Italy and the United Kingdom, and the similarities between the two countries in terms of political participatory trends and Facebook's penetration, Italy and the United Kingdom were deemed two interesting and potentially fruitful cases for a cross-national comparison.

\section{A mixed methods study}

The present article was methodologically inspired by the research of Kavanaugh et al. (2008) on the secondary effects (Sproull and Kiesler 1991) of the Internet on political participation. Accordingly, it adopted a sequential-explanatory mixed methods strategy. This research design entails a first quantitative phase, in which quantitative data are collected and analysed, followed by a qualitative phase, for a more detailed exploration of the phenomena under investigation (Ivankova et al. 2006). The data collection occurred in Italy and the United Kingdom during a period of similar electoral activity. Surveys were circulated on Facebook between March and June 2012, and interviews held between October and December 2012. During this timeframe, local elections took place in both countries in May, while no general elections were held. A total of 392 online surveys - 196 from the British participants (BPs) and 196 from the Italian participants (IPs) ${ }^{1}$ - were examined and their results further explored through 26 telephone/face- 
to-face interviews - thirteen for BPs and thirteen for IPs. ${ }^{2}$ Snowball sampling was employed in the first quantitative phase, while interviewees were selected through a combination of purposive and snowball sampling procedures. In the first phase of the study surveys were circulated on Facebook. The researcher's Facebook contacts were initially targeted - the targeted participants ensured a certain degree of variation in terms of demographics and levels of Facebook and political activity - and asked to circulate the surveys among their networks. Then, the quantitative samples were used as sampling frames for the qualitative stage of the research, and participants were selected on the basis of their scores on a number of key variables (e.g. age, Facebook political participation, etc.). As this process did not enable the recruitment of participants with profiles (i.e. young political activists, and individuals with low levels of political activity) deemed necessary to offer a full account of the contributions of Facebook to political participation, a further snowballing procedure was added.

It has to be noted that the adoption of non-probability sampling in the quantitative phase could have led to an error of coverage, which occurs when there is a difference between the target population $^{3}$ and the sampling frame in that some segments of the population are systematically excluded from the sample (Fricker 2008). In order to limit such an error the quantitative samples' sizes were calculated taking into account the sizes of the British and Italian Facebook populations at the time of the data collection, confidence intervals were applied and the samples obtained were post-stratified so that they mirrored the respective Facebook populations in terms of age. These counter-measures were adopted to try to increase the representativeness of the samples, but even so the generalizability that random samples would have guaranteed could not be achieved. 


\section{Data collection and analysis}

This article aims to explore the limitations of Facebook as a political platform. To this end, the levels of Facebook political participation and Facebook non-political activity were first compared. The goal of such a comparison was to determine how politics fits into a larger pattern of Facebook usage, and to what degree Facebook seems to be employed for non-political purposes. Online surveys were used to assess the respondents' participation in a number of nonpolitical and political activities. Participants were asked how often ( $1=$ Never, $2=$ Rarely, 3=Sometimes, 4=Often, 5=Very often) during the last six months they had engaged through Facebook in specific activities (see Table 1), and two summated rating scales - i.e. Facebook non-political activity (Cronbach's $\alpha=0.866$ ) and Facebook political participation (Cronbach's $\alpha=0.948)$ - were developed. 
Table 1: Facebook political participation and non-political activity - scales.

\begin{tabular}{|c|c|c|}
\hline Scales & Facebook non-political activity & Facebook political participation \\
\hline Items & $\begin{array}{l}\text { - Consuming non-political } \\
\text { news } \\
\text { • Visiting profiles of } \\
\text { non-political actors or } \\
\text { organizations } \\
\text { - Searching for non-political } \\
\text { initiatives } \\
\text { - Contacting family and } \\
\text { friends } \\
\text { - Non-political talk } \\
\text { - Sharing information on } \\
\text { non-political initiatives } \\
\text { - Posting/uploading nonpolitical } \\
\text { material } \\
\text { - Organizing non-political } \\
\text { initiatives } \\
\text { - Joining a non-political } \\
\text { group }\end{array}$ & $\begin{array}{l}\text { Organizing/participating in a } \\
\text { political initiative } \\
\text { - Forming/joining a group or } \\
\text { an organization developed } \\
\text { around politics } \\
\text { - Soliciting others to support } \\
\text { or oppose a particular political } \\
\text { party, candidate and/or } \\
\text { initiative } \\
\text { - Contacting a political party, } \\
\text { candidate, government } \\
\text { department and/or local } \\
\text { council } \\
\text { - Learning about a political } \\
\text { initiative, meeting, rally and/or } \\
\text { protest in which you took part } \\
\text { - Learning about a political } \\
\text { initiative, meeting, rally and/ } \\
\text { or protest } \\
\text { - Consuming political news } \\
\text { - Learning about a group or } \\
\text { an organization developed } \\
\text { around politics } \\
\text { - Engaging in formal and informal } \\
\text { political discussions } \\
\text { - Expressing a political opinion }\end{array}$ \\
\hline
\end{tabular}


Descriptive statistics were employed in order to analyse quantitative data and were deemed appropriate to the general exploratory purpose of the study. Non-parametric rather than parametric statistical techniques were applied due to the non-normal distribution of the data, and the ordinal or nominal nature of the questionnaire variables. The Kolmogorov-Smirnov test with Lilliefors (1967) correction - which is best used for sample sizes of more than 50 with unknown population mean and variance - was run to assess the normality of the distributions of scores. The test established that the data were not normally distributed $(p<0.05)$ and, consequently, medians rather than means and interquartile range (IQR) rather than standard variation were used.

Quantitative results were then supplemented and extended through the subsequent qualitative stage. Greene et al. (2001) observe that, used in isolation, survey research does not offer much in terms of explanation of findings, and in-depth interviews, when combined with this method, can illustrate and enhance quantitative findings. In this respect, interviews were employed to delve into the participants' participatory repertoires and explore the factors limiting political activity on Facebook. Qualitative data were examined through a thematic analysis, a method that enables analysis and interpretation of data through the identification of common patterns (Boyatzis 1998) and has been often used in qualitative studies investigating the links between SNSs and political participation (e.g. Gustafsson 2012; Marichal 2013; Storsul 2014). 


\section{Results and discussion: The limitations of Facebook as a political platform}

The limitations of Facebook as a political platform were, hence, explored in a two-step process.

First, Italian and British respondents' Facebook political participation was compared with their

Facebook non-political activity. After that, interviews were used to identify possible factors limiting political participation on this SNS.

\section{Facebook usage practices}

As shown in Table 2 and Figure 1, the comparison of Facebook political participation and Facebook non-political activity produced two main findings: (1) both British and Italian respondents engaged more often in Facebook non-political activities than in political ones; and (2) there was a discrepancy in terms of Facebook political participation among IPs and BPs, with the firsts slightly more active than BPs (the reasons behind such a participatory gap are not explored here as they are out of the remit of the article).

Table 2: Facebook political participation and non-political activity - descriptive statistics. ${ }^{1}$

\begin{tabular}{|c|c|c|c|c|}
\hline & \multicolumn{2}{|c|}{ British sample } & \multicolumn{2}{|c|}{ Italian sample } \\
\hline & Median & IQR & Median & IQR \\
\hline Facebook political participation & 15 & 14 & 24 & 18 \\
\hline Facebook non-political activity ${ }^{4}$ & 28 & 10 & 32 & 10 \\
\hline
\end{tabular}


Figure 1: Facebook political participation and non-political activity - box plots. ${ }^{1}$
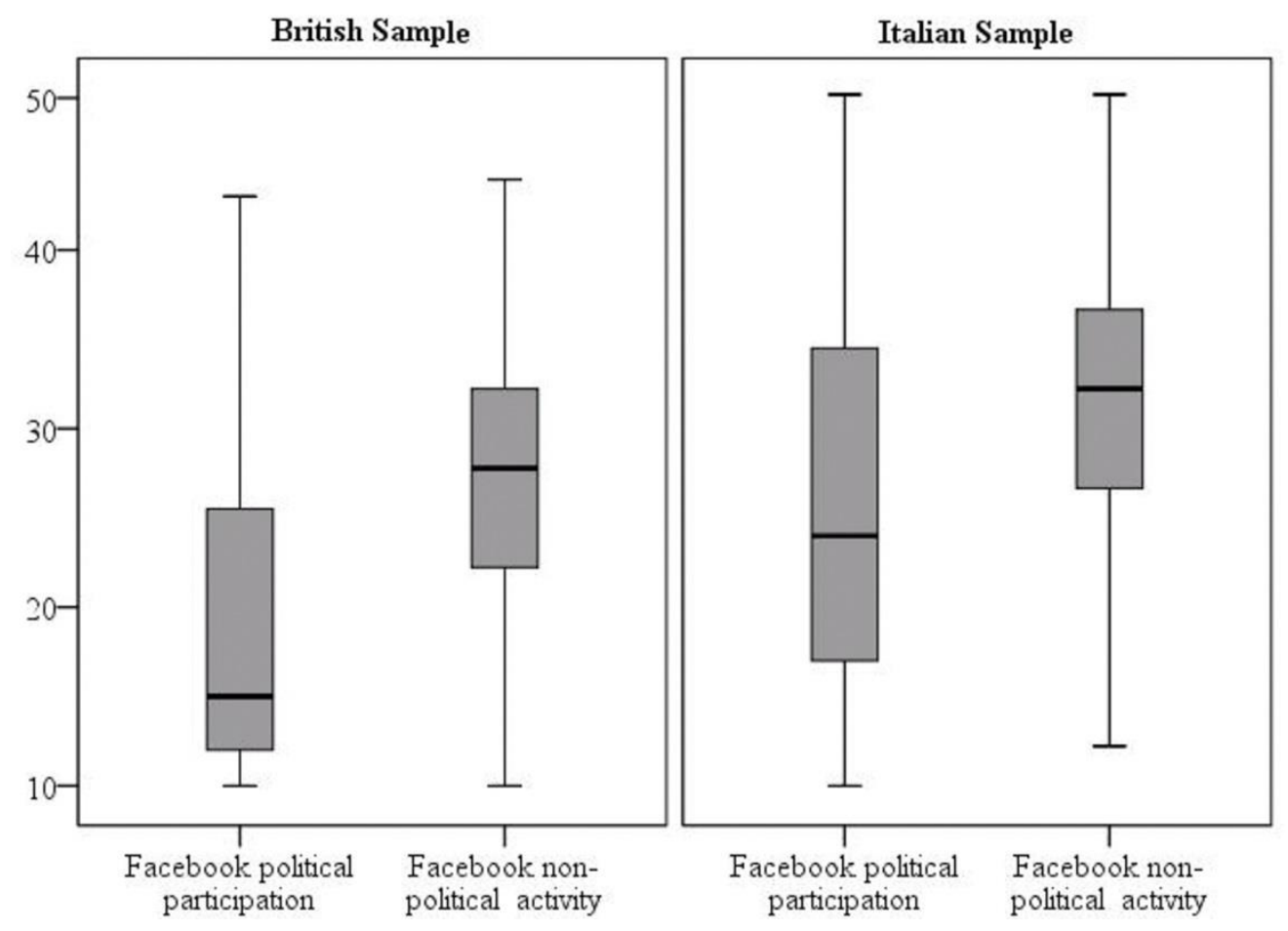

${ }^{[1]} 10$ (Never), 20 (Rarely), 30 (Sometimes), 40 (Often), 50 (Very often).

The dominantly non-political usage of Facebook was confirmed in the qualitative phase of the study. As illustrated in the following quotes, interviews showed that, except for certain users displaying particularly high levels of political participation and interest, Facebook was mainly used as a non-political platform.

\section{Mainly non-political usage}

Hilary - BP: 'I use Facebook more to connect with friends and I don't really like to bring politics into it [...] So I just keep Facebook as a sort of light-hearted [platform] [...] I don't even share my political views on Facebook' ${ }^{5}$ 
Ciro - IP: '[Facebook] is a social interface [...] For me it has mainly a social function' ${ }^{6}$

\section{Mainly political usage by highly politically active users}

Rachel - BP: 'I would define myself as a political animal [...] a lot of what I do on Facebook is either Political, with a big P, [related to party politics], or political, with a small $\mathrm{p}$ [related to single-issue and local campaigns]'.

Vincent - BP: 'I do keep in touch with old friends, university friends, school friends on Facebook, but mostly I use it for politics because this is what I'm interested in and most of my friends are interested in'.

Such findings offer support to the reinforcement thesis, i.e. SNSs reinforce existing participatory patterns by mainly aiding those citizens who are already politically active, and are consistent with findings of other studies indicating that political usages of SNSs are often overshadowed by social interaction and entertainment (Baumgartner and Morris 2010; Mascheroni 2012).

However, it has to be acknowledged that the results of the present research could have been influenced by the timescale of the data collection. Differing from numerous SNSs and political participation studies which focus heavily on the campaign environment (e.g. Towner 2013; Vitak et al. 2011), the data collection for the current investigation was carried out mostly during nonelectoral periods. Considering that political activity, both online and offline, fluctuates according to the proximity of elections, reaching its peaks in periods immediately prior to elections (Larson 2016), the choice of this specific timescale could have impacted negatively on the respondents' levels of political participation. In view of these considerations, while on the one hand it would 
be plausible to assume that Facebook is mainly used for non-political purposes, on the other hand it could be reasoned that the gap between political and non-political usages which surfaced in this article may close during electoral periods.

\section{The Facebook divide}

The thematic analysis of the interviews indicated three possible factors limiting the contributions of Facebook to political participation. One factor is the non-universality of Facebook, with some participants stressing that this SNS reaches only part of the British and Italian populations, and requires digital skills that not all individuals hold.

Need of digital skills

Kaye - BP: '[I don't participate much online and on Facebook because] I only had a computer for about 3 years. Before that I didn't have [one, and] I didn't use computers. I have learned fairly recently, so I would say it's still not second nature to me in the way that it will probably be to some young children who have grown up always having one'.

\section{Facebook usage gap}

Rachel - BP: 'Facebook is not yet universal. [For instance,] Friends of Union Terrace Gardens have members who are not online at all' ${ }^{7}$

Mario - IP: 'Anyone who organizes an event uses [Facebook] as the only tool and [...] probably this is a negative thing as people who do not participate digitally cannot get this information. We 
have to remember that Facebook is a niche $[\ldots]$ because there is a big part of the population who does not use this website'.

The non-universality of Facebook is confirmed by statistics on the penetration of this SNS that, at the time of the data collection, reached around 50 per cent of the British population, and approximately 40 per cent of the Italian population (Socialbakers 2012). Taking into account the notion of digital divide, which refers to the gap in access to and usage of digital technologies (van Dijk 2009), it would be possible to talk of the presence of a Facebook divide. With regards to the relevance of digital skills for Facebook political participation, data support the findings of Borrero et al. (2014) and Gangadharbatla et al. (2014) and show that proficiency in the usage of digital technologies can positively influence the likelihood of engaging in political activities on SNSs.

\section{The credibility of Facebook as a political information source}

A second limitation of Facebook as a political platform is its questionable credibility as a political information source. Although both Italian and British interviewees acknowledged the value and the growing relevance of Facebook as a source of political information, numerous participants stressed the abundance of bogus news and unreliable sources on Facebook.

\section{Issues of credibility of Facebook political information}

Lesley - BP: '[On Facebook] there are so many things that are urban myths [...] I think a lot of the causes [you find on there] are urban myths too and so I like to take time to have a look at some of the websites and check where the things are coming from'. 
Kaye - BP: 'Newspapers have to go over [the sources] they get their stories from, and make sure to some extent that these are as much as possible true, whereas [on Facebook] people can write any odd thing and $[\ldots]$ lots of people would probably believe it'.

Luca - IP: 'Facebook pays a price which is linked to its success. In my experience the so-called fakes - pictures that are not real, information that is not real, news that is not real - are certainly present'.

These findings support Johnson and Kaye (2014) who, comparing SNSs to eight other online information sources (i.e. political blogs, political websites, candidates' websites, candidates' blogs, YouTube, online broadcast TV news, online cable TV news and online newspapers), find that politically interested users rank these online platforms as the least credible sources. Likewise, Gangadharbatla et al. (2014) indicate that, despite preferring to use social media for newsgathering, young adults still perceive traditional media as more credible.

\section{The enduring relevance of the offline dimension}

A third limitation of Facebook as a political platform emerged from the interviews with British and Italian activists (i.e. individuals who displayed high levels of political mobilization). They considered Facebook a key tool for the organization and promotion of political initiatives, but also highlighted the enduring relevance of the offline dimension of political participation, describing their political activity on Facebook as rooted in and supporting their offline activity. 


\section{Interdependence between Facebook and offline political participation}

Francesca - IP: 'I think that Facebook supports political entities which already exist [...] the online cannot exist without the offline, while the offline could survive without the online'.

Antonio - IP: 'I think that Facebook is a very useful tool, in certain cases essential, but not sufficient on its own [...] Without offline organization, including small practical things such as requesting a square [for a rally], printing the flyers, organizing a press conference, etc. [...] [online activism] cannot work.'

In light of the strong links between Facebook and offline political activities, it could be argued that the mobilizing force of this SNS depends, at least in part, on its connection with the offline world, with Facebook best suited to support political entities that already exist and operate offline. Despite his techno-optimism, even Castells (2010) recognizes that the new social movements that use the Internet as their main organizational forum 'do not exist only on the Internet [but] also root themselves in their local lives, and in face to face interaction' (Castells 2010: 11), and can operate as a transformative force only by reclaiming urban spaces, i.e. the Occupy movement. Kavada (2010) also emphasizes that online communication does not necessarily lead to durable and effective activists' networks, with regular face-to-face meetings still necessary. Fuchs is even more categorical and argues that: 'there are no Twitter-, Facebookor YouTube-revolutions. Only people who live under certain social conditions and organize collectively can make rebellions and revolutions. Technology is, in itself, not a revolution' (2014: 102). 


\section{Bridging the online-offline divide}

This article explored the limitations of Facebook as a political platform. By focusing on Italy and the United Kingdom and seeking analogies between British and Italian Facebook users, it demonstrates the enduring relevance of the offline dimension for both mobilization-related and information/communication-oriented activities. In relation to the consumption of political information, British and Italian Facebook users express concerns about the credibility of the information circulated on Facebook, highlighting the abundance of bogus information and unreliable sources and acknowledging their continuing reliance on popular media broadcasters. Unsurprisingly, this is confirmed by several studies focusing on the Italian and British contexts that establish that TV remains the main source of political information, principally for older people, with the Internet and SNSs only gradually growing in importance, particularly for younger people (AGCOM 2013; Chadwick 2013; Cremonesi et al. 2014; Dutton and Blank 2013; Papathanassopoulos et al. 2013; Scaglioni and Sfardini 2013). Among the studies reported above, Papathanassopoulos et al.'s (2013) is particularly worth mentioning, as it also focuses among other countries (eleven in total) - on Italy and the United Kingdom. Their study indicates that, in nine out of eleven countries, television news remains at the top of the news hierarchy. Italy shows the highest average in terms of TV news consumption, while the exceptions are Norway and South Korea, two countries whose populations have widespread access to broadband Internet and in which the Internet is the main source of news (Papathanassopoulos et al. 2013).

The enduring relevance of the offline dimension is also confirmed with regards to the mobilization dimension of political participation. Interviews with British and Italian activists indicate that the offline world cannot be ignored, and suggest that in order to develop effective 
political campaigns political entities have to cater also to those individuals who are not online. The quote from Rachel offers an example of how integration of both new and more traditional methods can overcome this usage (often generational) gap. Rachel mentioned the case of Friends of Union Terrace Gardens, and explained that in order to reach its older members; this organization has combined online communication tools (i.e. Facebook page and website) with more traditional methods such as letters.

The strong connection between the online and offline dimensions of political participation is arguably linked to the hybrid nature of today's media. Taking into account the changes in today's political communication environments due to the diffusion of new communication technologies, Chadwick develops the notion of the hybrid media system, which 'is built upon interactions among old and new media logics - where logics are defined as technologies, genres, norms, behaviours, and organizational forms - in the reflexively connected fields of media and politics' (2013: 4).

The findings presented in this article confirm the hybridity of the British and Italian political communication environments and offer indications on how political organizations, candidates and movements could harness Facebook and online media more generally. Despite its penetration, Facebook remains, in fact, a niche. Accordingly, when activists use this SNS or any other digital platform as the only mobilization tool, they deprive the citizens who are not on these platforms of a wealth of information and, consequently, limit their reach. As shown by the British political activist movement 38 Degrees and the Italian political party Movimento 5 Stelle - Five Stars Movement - which integrate offline and online repertoires to their advantage (Bordignon and Ceccarini 2013; Chadwick 2013), integration of new and traditional media can overcome the online-offline divide and is, arguably, a far more effective strategy. 


\section{Conclusions: Integration and hybridity}

In recent years, SNSs have become a hot topic for academics all over the world, with an increasing number of publications focusing on how these platforms can contribute to political participation. A review of the literature has shown that many studies paint a picture of positive effects and celebrate the mobilization and emancipatory affordances of SNSs (e.g. Castells 2012; Baek 2015). Other scholars emphasize the tendency of SNSs to reinforce existing participatory patterns (e.g. Vesnic-Alujevic 2012; Vitak et al. 2011), or adopt a more critical stance highlighting the drawbacks of these platforms (e.g. Fenton and Barassi 2011; Fuchs 2014). Drawing from an extensive and original data set acquired by combining a cross-national comparative approach and a mixed methods methodology, this article complements the work of this latter group of scholars and explores the limitations of Facebook as a political platform. By focusing on the similarities between British and Italian Facebook users, this article attempts to offer a critical reflection that goes beyond national contexts. In doing so it identifies three general inhibitors of Facebook political participation: the non-universality of Facebook, its

questionable credibility as a political information source and the enduring relevance of the offline dimension of political participation.

Facebook is just one tool in the extensive and diverse political arsenal available to citizens. In order to think beyond the unrealistic predictions often characterizing the field and to truly contribute to its development, it is necessary to recognize that SNSs cannot be studied in isolation but need to be assessed within the hybrid media systems (Chadwick 2013) in which they operate. The SNSs are not a 'magic elixir' capable to increase citizens' participation and reverse the democratic deficit characterizing western democracies (Norris 2011). The most 
effective way in which they can aid political participation is, perhaps, by bridging the onlineoffline divide, integrating and supporting other media and offline activities. 


\section{References}

AGCOM (2013), 'Indagine Conoscitiva sul Settore dei Servizi Internet e sulla Pubblicità online’, http://www.agcom.it. Accessed 12 January 2014.

Ancu, M. and Cozma, R. (2009), 'MySpace politics: Uses and gratifications of befriending candidates', Journal of Broadcasting \& Electronic Media, 53:4, pp. 567-83.

Baek, Y. M. (2015), 'Political mobilization through social network sites: The mobilizing power of political messages received from SNS friends', Computers in Human Behavior, 44:1, pp. $12-19$.

Bae, S. Y. (2013), 'A trigger or a muffler? Examining the dynamics of crosscutting exposure and political expression in online social media', eJournal of eDemocracy and Open Government, 5:1, pp. 16-27.

Baresch, B., Knight, L., Harp, D. and Yaschur, C. (2011), 'Friends who choose your news: An analysis of content links on Facebook', ISOJ: The Official Research Journal of International Symposium on Online Journalism, 1:2, pp. 65-85

Baumgartner, J. C. and Morris, J. S. (2010), 'MyFaceTube politics: Social networking web sites and political engagement of young adults', Social Science Computer Review, 28:1, pp. $24-44$. 
Bimber, B. (2003), Information and American Democracy: Technology in the Evolution of Political Power, New York: Cambridge University Press.

Bond, R., Fariss, C., Jones, J., Kramer, A., Marlow, C., Settle, J. and Fowler, J. (2012), ‘A 61million-person experiment in social influence and political mobilization', Nature, 489:7415, pp. 295-98.

Bordignon, F. and Ceccarini, L. (2013), 'Five stars and a cricket: Beppe Grillo shakes Italian politics', South European Society and Politics, 18:4, pp. 427-49.

Borrero, J. D., Yousafzai, S. Y., Javed, U. and Page, K. L. (2014), 'Expressive participation in Internet social movements: Testing the moderating effect of technology readiness and sex on student SNS use', Computers in Human Behavior, 30:1, pp. 39-49.

Boulianne, S. (2015), 'Social media use and participation: A meta-analysis of current research', Information, Communication \& Society, 18:5, pp. 524-38.

Boyatzis, R. E. (1998), Transforming Qualitative Information: Thematic Analysis and Code Development, Thousand Oaks: SAGE Publications.

Carlisle, J. E. and Patton, R. C. (2013), 'Is social media changing how we understand political engagement? An analysis of Facebook and the 2008 presidential election', Political Research Quarterly, 66:4, pp. 883-95. 
Castells, M. (1996), The Rise of the Network Society, Oxford: Blackwell Publishing.

(2010), 'Communication power: Mass communication, mass self-communication, and power relationships in the network society', in J. Curran (ed.), Media and Society, 5th ed., London: Bloomsbury, pp. 3-17.

(2012), Networks of Outrage and Hope: Social Movements in the Internet Age, Cambridge: Polity Press.

Casteltrione, I. (2015), 'The Internet, social networking web sites and political participation research: Assumptions and contradictory evidence', First Monday, 20:3, http://dx.doi.org/10.5210/fm.v20i3.5462. Accessed 18 January 2016.

(2016), 'Facebook and political participation: Virtuous circle and participation intermediaries', Interactions: Studies in Communication \& Culture, 7:2, pp. 177-96.

Chadwick, A. (2013), The Hybrid Media System: Politics and Power, Oxford: Oxford University Press.

Chadwick, A. and Howard, P. N. (eds) (2009), The Routledge Handbook of Internet Politics, Abington: Routledge.

Chaffee, S. H. (ed.) (1975), Political Communication, Beverly Hills, CA: Sage Publications. 
Christy, C. A. (1987), Sex Differences in Political Participation: Processes of Change in Fourteen Nations, New York: Praeger Publishers.

Cremonesi, C., Legnante, G. and Ruffino, L. (2014), 'Old and new patterns of media consumption', Comunicazione Politica, 14:1, pp. 29-46.

Curran, J., Coen, S., Soroka, S., Aalberg, T., Hayashi, K., Hichy, Z., Iyengar, S., Jones, P., Mazzoleni, G., Papathanassopoulos, S., Rhee, J. W., Rojas, H., Rowe, D. and Tiffen, R. (2014), 'Reconsidering "virtuous circle" and "media malaise" theories of the media: An 11-nation study', Journalism, 15:7, pp. 815-33.

Dahl, R. A. (1961), 'The behavioral approach in political science: Epitaph for a monument to a successful protest', The American Political Science Review, 55:4, pp. 763-72.

Dijk, J. A. G. M. van (2009), 'One Europe, digitally divided', in A. Chadwick and P. N. Howard N. (eds), The Routledge Handbook of Internet Politics, Abington: Routledge, pp. 288304.

Donovan, M. and Onofri, P. (2008), Italian Politics: Frustrated Aspirations for Change, Oxford: Berghahn Books. 
Dutton, W. H. and Blank, G. (2013), Cultures of the Internet: The Internet in Britain, Oxford Internet Survey 2013 Report, Oxford: Oxford Internet Institute, http://oxis.oii.ox.ac.uk. Accessed 20 March 2014.

Ellison, N. B., Steinfield, C. and Lampe, C. (2007), 'The benefits of Facebook "friends": Social capital and college students' use of online social network sites', Journal of ComputerMediated Communication, 12:4, pp. 1143-68.

Facebook (2017), 'Adverts manager’, https://www.facebook.com/ads/manager/creation/creation. Accessed 10 January 2017.

Fenton, N. and Barassi, V. (2011), 'Alternative media and social networking sites: The politics of individuation and political participation', The Communication Review, 14:3, pp. 17996.

Fricker, R. D. Jr. (2008), 'Sampling methods for web and e-mail surveys', in N. Fielding, R. M. Lee and G. Blank (eds), The SAGE Handbook of Online Research Methods, London: Sage Publications, pp. 195-216.

Fuchs, C. (2014), Social Media: A Critical Introduction, London: Sage Publications. 
Gangadharbatla, H., Bright, L. F. and Logan, K. (2014), 'Social Media and news gathering: Tapping into the millennial mindset', The Journal of Social Media in Society, 3:1, pp. 45-63.

Gil de Zúñiga, H., Jung, N. and Valenzuela, S. (2012), 'Social media use for news and individuals' social capital, civic engagement and political participation', Journal of Computer-Mediated Communication, 17:3, pp. 319-36.

Greene, J. C., Benjamin, L. and Goodyear, L. (2001), 'The merits of mixing methods in evaluation', Evaluation, $7: 1$, pp. 25-44.

Guest, G., Bunce, A. and Johnson, L. (2006), How many interviews are enough? An experiment with data saturation and variability', Field Methods, 18:1, pp. 59-82.

Gustafsson, N. (2012), 'The subtle nature of Facebook politics: Swedish social network site users and political participation', New Media \& Society, 14:7, pp. 1111-27.

Holt, K., Shehata, A., Strömbäck, J. and Ljungberg, E. (2013), 'Age and the effects of news media attention and social media use on political interest and participation: Do social media function as leveller?', European Journal of Communication, 28:1, pp. 19-34.

Ivankova, N. V., Creswell, J. W. and Stick, S. (2006), 'Using mixed methods sequential explanatory design: From theory into practice', Field Methods, 18:1, pp. 3-20. 
Johnson, T. J. and Kaye, B. K. (2014), 'Credibility of social network sites for political information among politically interested Internet users', Journal of Computer-Mediated Communication, 9:4, pp. 957-74.

Kavada, A. (2010), 'Activism transforms digital: The social movement perspective', in M. Joyce (ed.), Digital Activism Decoded: The New Mechanics of Change, New York: TInternational Debate Education Association, pp. 101-18.

Kavanaugh, A., Kim, B. J., Perez-Quinones, M. A., Schmitz, J. and Isenhour, P. (2008), 'Net gains in political participation: Secondary effects of internet on community', Information, Communication \& Society, 11:7, pp. 933-63.

Kim, J. and Kim, E. J. (2008), 'Theorizing dialogic deliberation: Everyday political talk as communicative action and dialogue', Communication Theory, 18:1, pp. 51-70.

Kushin, M. J. and Kitchener, K. (2009), 'Getting political on social network sites: Exploring online political discourse on Facebook', First Monday, 14:11, http://dx.doi.org/10.5210/fm.v14i11.2645. Accessed 18 March 2014.

Landman, T. (2008), Issues and Methods in Comparative Politics: An Introduction, 3rd ed., Oxon: Routledge. 
Larson, A. O. (2016), 'Online, all the time? A quantitative assessment of the permanent campaign on Facebook', New Media \& Society, 18:2, pp. 274-92.

Lievrouw, L. A. (2009), 'New media, mediation, and communication study', Information, Communication \& Society, 12:3, pp. 303-25.

Lilliefors, H. W. (1967), 'On the Kolmogorov-Smirnov test for normality with mean and variance unknown', Journal of the American Statistical Association, 62:318, pp. 399402.

Lim, M. (2012), 'Clicks, cabs, and coffee houses: Social media and oppositional movements in Egypt, 2004-2011', Journal of Communication, 62:2, pp. 231-48.

Livingstone, S. (2003), 'On the challenges of cross-national comparative media research', European Journal of Communication, 18:4, pp. 477-500.

Marichal, J. (2013), 'Political Facebook groups: Micro-activism and the digital front stage', First Monday, 18:12, http://dx.doi.org/10.5210/fm.v18i12.4653. Accessed 18 March 2014.

Mascheroni, G. (2012), 'Online participation: New forms of civic and political engagement or just new opportunities for networked individualism', in B. D. Loader and D. Mercea (eds), Social Media and Democracy: Innovations in Participatory Politics, Oxon: Routledge, pp. 207-23. 
Mitchell, A., Kiley, J., Gottfried, J. and Guskin, E. (2013), 'The role of news on Facebook common yet incidental', Pew Research Center: Journalism and Media, www.journalism.org. Accessed 12 October 2014.

Morozov, E. (2011), The Net Delusion: How Not to Liberate the World, London: Penguin Books.

Moutinho, L. and Hutcheson, G. (2011), The SAGE Dictionary of Quantitative Management Research, London: Sage Publications.

Moy, P., Bimber, B., Rojecki, A., Xenos, M. A. and Iyengar, S. (2012), 'Shifting contours in political communication research', International Journal of Communication, 6, pp. 24754.

Norris, P. (2011), Democratic Deficit: Critical Citizens Revisited, New York: Cambridge University Press.

Nowak, S. (1977), 'The strategy of cross-national survey research for the development of social theory', in A. Szalai and R. Petrella (eds), Cross-national Comparative Survey Research: Theory and Practice, Oxford: Pergamon Press, pp. 3-47.

Obar, J. A., Zube, P. and Lampe, C. (2012), 'Advocacy 2.0: An analysis of how advocacy groups in the United States perceive and use social media as tools for facilitating civic 
engagement and collective action', Journal of Information Policy, 2, pp. 1-25, 10.5325/jinfopoli.2.2012.0001. Accessed 12 October 2014.

Papacharissi, Z. (2015), Affective Publics: Sentiment, Technology, and Politics, New York: Oxford University Press.

Papathanassopoulos, S., Coen, S., Curran, J., Aalberg, T., Rowe, D., Jones, P., Rojas, H. and Tiffen, R. (2013), 'Online threat, but television is still dominant', Journalism Practice, 7:6, pp. 690-704.

Rainie, L. and Smith, A. (2012), 'Politics on social networking sites', The Pew Research Center: Internet, Science \& Tech, www.pewinternet.org. Accessed 9 January 2014.

Ryfe, D. M. (2001), 'History and political communication: An introduction', Political Communication, 18:4, pp. 407-20.

Scaglioni, M. and Sfardini, A. (2013), 'Audipol Elezioni politiche 2013: Il potere della Tv e la forza dei talk show', Comunicazione Politica, 13:2, pp. 273-76.

Semetko, H. and Scammell, M. (eds) (2012), The SAGE Handbook of Political Communication, London: SAGE Publications. 
Socialbakers (2012), 'Facebook statistics by nation', www.socialbakers.com. Accessed 20 January 2012.

Sproull, L. and Kiesler, S. (1991), Connections: New Ways of Working in the Networked Organization, Cambridge, MA: MIT Press.

Storsul, T. (2014), 'Deliberation or self-presentation? Young people, politics and social media', Nordicom Review, 35:2, pp. 17-28.

Tedesco, J. C. (2004), 'Changing the channel: Use of the Internet for communicating about politics', in L. L. Kaid (ed.), Handbook of Political Communication Research, Mahwah: Lawrence Erlbaum Associates, pp. 507-32.

Theocharis, Y. (2011), 'Young people, political participation and online postmaterialism in Greece', New Media \& Society, 13:2, pp. 203-23.

Towner, T. L. (2013), 'All political participation is socially networked? New media and the 2012 election', Social Science Computer Review, 31:5, pp. 527-41.

Valenzuela, S., Arriagada, A. and Scherman, A. (2012), 'The social media basis of youth protest behavior: The case of Chile', Journal of Communication, 62:2, pp. 299-314. 
Vedel, T. (2007), Les usages politiques d'internet, La démocratie électronique, Paris: Ed. La Documentation française.

Verba, S., Brady, H. E. and Schlozman, K. L. (1995), Voice and Equality: Civic Voluntarism in American Politics, Cambridge, MA: Harvard University Press.

Vesnic-Alujevic, L. (2012), 'Political participation and web 2.0 in Europe: A case study of Facebook', Public Relations Review, 38:3, pp. 466-70.

Vitak, J., Zube, P., Smock, A., Carr, C., Ellison, N. and Lampe, C. (2011), 'It's complicated: Facebook users' political participation in the 2008 election', Cyberpsychology, Behavior, and Social Networking, 14:3, pp. 107-14.

Vromen, A., Xenos, M. A. and Loader, B. (2015), 'Young people, social media and connective action: From organizational maintenance to everyday political talk', Journal of Youth Studies, 18:1, pp. 80-100.

Warnick, D. P. and Osherson, S. (1973), 'Comparative analysis in the social sciences', in D. P. Warnick and S. Osherson (eds), Comparative Research Method, Englewood Cliffs: Prentice Hall, pp. 3-41.

Warren, A. M., Sulaiman, A. and Jaafar, N. I. (2014), 'Facebook: The enabler of online civic engagement for activists', Computers in Human Behavior, 32, pp. 284-89. 
Weeks, B. E. and Holbert, R. L. (2013), 'Predicting dissemination of news content in social media: A focus on reception, friending, and partisanship', Journalism \& Mass Communication Quarterly, 90:2, pp. 212-32.

Whiteley, P. (2012), Political Participation in Britain: The Decline and Revival of Civic Culture, Basingstoke: Palgrave Macmillan.

Wright, S., Graham, T. and Jackson, D. (2016), 'Third Space, social media and everyday political talk', in A. Bruns, E. Skogerbø, C. Christensen, A. O. Larsson and G. Enli (eds), The Routledge Companion to Social Media and Politics, New York: Routledge, pp. 74 88.

Xenos, M., Vromen, A. and Loader, B. D. (2014), 'The great equalizer? Patterns of social media use and youth political engagement in three advanced democracies', Information, Communication \& Society, 17:2, pp. 151-67.

Yoo, S. and Gil de Zúñiga, H. (2014), 'Connecting blog, Twitter and Facebook use with gaps in knowledge and participation', Communication \& Society, 27:4, pp. 33-50. 
Notes

${ }^{1}$ Taking into account the sizes of the British and Italian Facebook populations, using a confidence interval of 95 per cent and allowing for a 7 per cent error, it was calculated that both samples required 196 participants.

${ }^{2}$ The number of participants to be interviewed was decided on the basis of guidelines for the definition of size of qualitative samples (Guest et al. 2006).

${ }^{3}$ To be eligible for the study, participants had to be Facebook users, between the age of 18 and 65, and either British or Italian citizens.

${ }^{4}$ Given the different number of items forming the two scales (10 vs 9), respondents' scores on the Facebook non-political activity scale have been ratioed up.

${ }^{5}$ Fictional names are used in order to protect participants' privacy and anonymity.

${ }^{6}$ Interviews with IPs were conducted in Italian and quotes were translated to English by the researcher.

${ }^{7}$ The Friends of Union Terrace Gardens is a Scottish organization aiming to prevent large-scale development in Aberdeen's Union Terrace Gardens. 